STUDIA I PRACE WYDZIAŁU NAUK EKONOMICZNYCH I ZARZĄDZANIA NR 40, T. 2

DOI: $10.18276 / \operatorname{sip} .2015 .40 / 2-10$

\author{
Aleksandra Milczarek* \\ Uniwersytet Szczeciński
}

\title{
WYBRANE ASPEKTY ZACHOWAŃ KONSUMENTÓW W KONTEKŚCIE ZROWNOWAŻONEJ KONSUMPCJI
}

\section{STRESZCZENIE}

W artykule podjęto tematykę decyzji i zachowań współczesnych konsumentów. Zasadniczym celem pracy jest wskazanie i ocena najnowszych trendów w zakresie konsumpcji oraz rozwoju tzw. inteligentnej konsumpcji. Rozważania dotyczą jedynie polskich konsumentów. W kontekście założeń zrównoważonej konsumpcji przeanalizowano również skutki i znaczenie obserwowanych zachowań konsumenckich dla gospodarki.

Słowa kluczowe: konsumpcja, podejmowanie decyzji, konsumpcja zrównoważona, konsumpcja inteligentna

\section{Wprowadzenie}

Decyzje podmiotów rynkowych we współczesnej gospodarce w wielu przypadkach przeczą zasadom racjonalności głoszonym przez klasyczne teorie ekonomii. W szczególności dotyczy to decyzji konsumpcyjnych, warunkujących zróżnicowane zachowania jednostek. Postęp, Internet, powszechne korzystanie z mobilnych sprzętów elektronicznych oraz procesy globalizacji przyczyniły się do rewolucji w zakresie możliwości zakupowych współczesnych konsumentów oraz wykształcenia się całkowicie nowych trendów konsumenckich. W związku z popularnymi w ostatnich

\footnotetext{
*Adres e-mail: olamilczarek86@op.pl.
} 
latach hasłami proekologicznymi oraz realizacją licznych projektów i strategii zrównoważonego rozwoju, poszukiwano również nowych podstaw decyzji konsumentów. Pojawiło się zatem pojęcie konsumpcji zrównoważonej czy też konsumpcji inteligentnej. Liczba jej zwolenników z roku na rok rośnie, przez co charakterystyczne dla niej zachowania konsumentów będą miały coraz większy wpływ na gospodarkę. Podmioty rynkowe będą stopniowo zmuszane do przemian i dostosowywania się do oczekiwań bardziej świadomych i wymagających klientów, a ci, którzy się nie dostosują, będą narażeni na powolną utratę udziałów w rynku.

W artykule podjęto tematykę zachowań współczesnych konsumentów. Zasadniczym celem pracy jest wskazanie i ocena najnowszych trendów w zakresie konsumpcji w Polsce oraz rozwoju tzw. inteligentnej konsumpcji. Analizie opartej na danych statystycznych została poddana konsumpcja przy wykorzystaniu narzędzi e-commerce, konsumpcja inteligentna oraz konsumpcja oparta na współdzieleniu i współużytkowaniu. Powiązanie wskazanych trendów z założeniami konsumpcji zrównoważonej posłuży do omówienia skutków i znaczenia obserwowanych zachowań konsumenckich dla gospodarki.

\section{Konsumpcja}

Konsumpcja, która w ujęciu makroekonomicznym utożsamiana jest przede wszystkim ze spożyciem indywidualnym przez gospodarstwa domowe, to jedna z podstawowych wielkości tworząca produkt krajowy brutto we współczesnych gospodarkach. Jej udział w PKB w Polsce wynosi ok. 60\% ${ }^{1}$. Wielkość konsumpcji poszczególnych jednostek uzależniona jest głównie od osiąganych dochodów oraz cen rynkowych, jednak na konsumpcję wpływać będą również takie czynniki, jak: wiek, płeć, miejsce zamieszkania, gusta i preferencje, indywidualne cechy charakteru, liczba osób w rodzinie czy wyznawane wartości. W kręgu zainteresowań ekonomistów znalazła się dodatkowo psychologia zachowań, gdyż coraz wyraźniej zarysowuje się wpływ aspektów behawioralnych na decyzje konsumenckie. James B. Watson określił zachowanie jako rezultat uwarunkowań środowiskowych, gdyż to otoczenie zewnętrzne i płynące z niego bodźce determinują zachowania człowieka². W tym rozumieniu Watson za jedyną wiarygodną podstawę badań psychologicznych uznawał zachowania dające zaobserwować się z zewnątrz.

${ }^{1}$ Maty Rocznik Statystyczny Polski 2014, GUS, Warszawa 2014, s. 482.

2 D.M. Buss, Psychologia ewolucyjna, Gdańskie Wydawnictwo Psychologiczne, Gdańsk 2001, s. 46. 
Klasyczne modele ekonomiczne wskazują kilka podstawowych założeń dotyczących ekonomicznych zachowań człowieka. Według nich człowiek²

- dokonuje racjonalnych wyborów,

- podejmując decyzje, maksymalizuje korzyści,

- jest egoistą i ignoruje wyniki innych podmiotów w interakcji ekonomicznej,

- poprawnie kalkuluje prawdopodobieństwo,

- ma stałe preferencje,

- wszystkie źródła dochodów traktuje zamiennie.

Obserwacja jednostek podczas procesu podejmowania decyzji wyraźnie pokazuje, że założenia te nie są spójne z rzeczywistością. Wystarczy zajrzeć do koszyka przeciętnego klienta supermarketu, który przyszedł do sklepu po coś konkretnego, a wychodzi z czymś całkowicie innym. Podmioty nie zawsze wybierają rozwiązanie optymalne i nie wszyscy w każdym swoim działaniu dążą do maksymalizacji zysków. Jest wielu na tym świecie altruistów, którzy dla dobra innych rezygnują z własnych korzyści. Dla sporej części społeczeństwa umiejętność korzystania z danych probabilistycznych w procesie podejmowania decyzji jest nieznana ${ }^{4}$. Preferencje również nie są stałe, np. w sytuacji zmiany otoczenia opcji wyboru kolejny wybór będzie różnił się od pierwsze$\mathrm{go}^{5}$. Wynika z tego, że także decyzje dotyczące konsumpcji nie są w pełni racjonalne i przeczą założeniom klasyków. Poza tym człowiek bardzo często kieruje się uczuciami i emocjami, w szczególności w przypadku szybkich i spontanicznych wyborów. Od zachowań zatem będzie zależała decyzja o konsumpcji określonych dóbr i usług.

Ekonomia dobrobytu, tutaj w rozumieniu działań zmierzających do zwiększania zadowolenia, silnie akcentuje nadmierną wręcz konsumpcję i prawo własności. Trafnym stwierdzeniem jest to, że jednostka w samoocenie i odbiorze społecznym stała się tym, co posiada i co konsumuje ${ }^{6}$. Tymczasem jednak nastąpiło przesycenie nadmiarem rzeczy i przeszacowanie wartości społeczeństw. Nowe przedmioty dawały szczęście tylko przez chwilę, później stawały się nudne, a człowieka zaczął przytłaczać ogrom posiadanych dóbr.

3 T. Zaleśkiewicz, Psychologia ekonomiczna, Wydawnictwo Naukowe PWN, Warszawa 2013, s. 21-26.

${ }^{4}$ Potwierdzają to wyniki badań m.in. Veroniki Denes-Rej i Seymour Epstein (1994).

${ }^{5}$ Zob. G. Loewenstein, D. Prelec, Anomalies in Intertemporal Choice: Evidence and an Interpretation, „Quarterly Journal of Economics”, May 2012, s. 573-597.

${ }^{6}$ A. Olejniczuk-Merta, Zmiany w konsumpcji i zachowaniach konsumentów, w: Społeczno-ekonomiczne determinanty konsumpcji w Polsce, red. U. Łangowska-Szczęśniak, A. Bobrowska, Wydawnictwo Uniwersytetu Opolskiego, Opole 2011, s. 9-30. 
Konsumpcja, jako siła napędowa całej gospodarki, traktowana była jak społeczny obowiązek. Zwiększenie wydatków przez gospodarstwa domowe zwiększało produkcję, dawało miejsca pracy oraz wspierało rozwój gospodarczy kraju, a tym samym i poprawiało dobrobyt. Konsumpcja była więc swoistym gwarantem stabilności ekonomicznej. Z drugiej jednak strony jej wzrost oznaczał narastający problem odpadów oraz coraz większą degradację środowiska. Pojawił się dylemat, czy ograniczać konsumpcję kosztem pogorszenia sytuacji gospodarczej, czy jednak dalej ją zwiększać. Problem ten rozwiązały nowe trendy w tym zakresie, dzięki którym mniejsze wydatki nie są równoznaczne z osłabieniem wzrostu gospodarczego ${ }^{7}$. Konsumenci nauczyli się konsumpcji zrównoważonej i inteligentnej, przechodząc od ekonomii dobrobytu, nastawionej na jak największe posiadanie, do ekonomii umiaru, czyli posiadania „w sam raz”. Dzięki temu rozwija się tendencja nabywania jedynie rzeczy niezbędnych. Co więcej, jak pokazuje raport Havas Worldwide „Nowy typ konsumentów i gospodarka oparta na współdzieleniu"9, ponad połowa Polaków (52\%) może się obyć bez większości rzeczy, które posiada.

Konsumpcja inteligentna oznacza konsumpcję wyższej jakości, nacechowaną celowością i spójną z wyznawanymi wartościami. Pojawia się współtworzenie dóbr i usług przez konsumentów oraz współpraca $\mathrm{z}$ firmami ${ }^{10}$. Lekkomyślne zakupy zastępowane są rozważnym podejmowaniem decyzji. Nabywa się jedynie rzeczy niezbędne, zwracając uwagę na jakość dóbr, gdyż następuje wydłużenie okresu ich używalności poprzez recykling lub zmianę przeznaczenia, co ogranicza marnotrawstwo. W ramach inteligentnych zakupów wykształca się również tendencja do wspólnego nabywania i współużytkowania produktów ${ }^{11}$.

7 J.H. Spangenberg, S. Lorek, Lebensqualität, Konsum und Umwelt: intelligente Lösungen statt unnötiger Gegensätze, Gutachten, SERI Sustainable Europe Research Institute, Köln-Wien 2003, s. 17.

8 Privater Konsum und Nachhaltige Entwicklung, red. H. Leitschuh-Fecht, S. Lorek, Positionspapier des Forum Umwelt \& Entwicklung, Positionspapier zur Vorlage bei der CSD 7, Bonn 1999, s. 4-5.

${ }^{9} \mathrm{http}$ //informacje.havasworldwide.pl/pr/286856/inteligentna-konsumpcja-i-rola-marek-w-obliczuekonomii-w-sam-raz?rss=true $($ dostęp 30.03.2015).

${ }^{10}$ E. Abramek, Prosumpcja w rozwoju systemów informatycznych zarzadzania, w: Innowacje $w$ zarzadzaniu i inżynierii produkcji, red. R. Knosala, Oficyna Wydawnicza Polskiego Towarzystwa Zarządzania Produkcją, Opole 2013, s. 14.

${ }^{11}$ Raport Havas Worldwide, Nowy typ konsumentów i gospodarka oparta na współdzieleniu, http://informacje.havasworldwide.pl/pr/286856/inteligentna-konsumpcja-i-rola-marek-w-obliczuekonomii-w-sam-raz?rss=true (dostęp 30.03.2015). 
Natomiast konsumpcja zrównoważona to konsumpcja wyznaczana przez proekologiczne wartości i postawy konsumenta, które budują świadomość ekologiczną oraz prowadzą do ekologicznie i społecznie odpowiedzialnego podejmowania decyzji rynkowych ${ }^{12}$. Jej przejawem jest oszczędne i racjonalne spożywanie dóbr konsumpcyjnych i zasobów naturalnych, a także świadome i celowe ograniczanie konsumpcji produktów wymagających dużego zużycia rzadkich, nieodnawialnych zasobów oraz generujących znaczne ilości odpadów ${ }^{13}$.

\section{Zachowania konsumpcyjne w Polsce}

Nowe technologie stały się obecnie jednym z popularniejszych sposobów dokonywania zakupów i otworzyły nowe możliwości zakupowe dla całych społeczeństw, także w Polsce. Z narzędzi e-commerce, czyli handlu elektronicznego, korzysta już 17,73 mln Polaków, czyli 78\% internautów. Jest to ponad 4 mln więcej niż w 2009 roku. Na przestrzeni 5 lat liczba użytkowników e-commerce zwiększyła się o 36\%, podczas gdy w tym samym czasie liczba internautów wzrosła o $30 \%{ }^{14}$.

Rysunek 1. Popularność narzędzi e-commerce w Polsce w 2014 roku

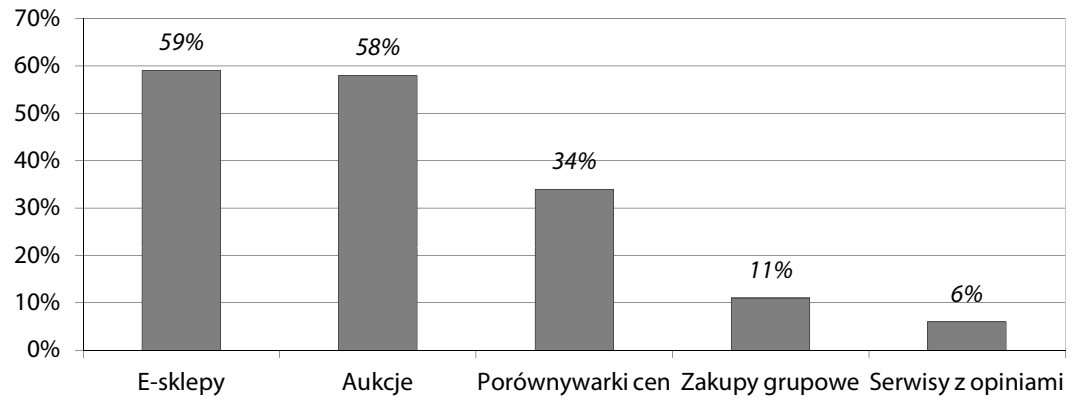

Źródło: Raport Izby Gospodarki Elektronicznej: Kupuję w internecie 2014...

12 J. Zrałek, Dekonsumpcja jako przejaw konsumpcji zrównoważonej i jej konsekwencje dla marketingu, „Handel Wewnętrzny”, maj-czerwiec 2013, t. I, s. 105.

${ }^{13}$ B. Kryk, Zrównoważona jakość życia a zrównoważona konsumpcja i zachowania ekologiczne polskich konsumentów, „Handel Wewnętrzny”, listopad-grudzień 2013, t. II, s. 5-19.

${ }^{14}$ Raport Izby Gospodarki Elektronicznej, Kupuję w internecie 2014, www.ecommercepolska.pl (dostęp 21.03.2015). 
Konsumenci dokonujący zakupów przez Internet korzystają z takich narzędzi, jak: sklepy internetowe, aukcje, wyszukiwarki produktów, porównywarki cen, serwisy z opiniami, czy zakupy grupowe. Ich popularność w Polsce w 2014 roku przedstawiono na rysunku 1 .

Największą popularnością wśród polskich internautów w 2014 roku cieszyły się e-sklepy oraz aukcje. Korzystało z nich prawie $60 \%$ użytkowników. 1/3 przed zakupem sprawdzała ceny w porównywarkach cen. $Z$ zakupów grupowych korzystał co dziesiąty ankietowany, natomiast z serwisów z opiniami innych użytkowników na temat dóbr korzystało jedynie 6\%. Motywy zakupów online przedstawiono na rysunku 2.

Rysunek 2. Motywy zakupów online polskich internautów w 2014 roku

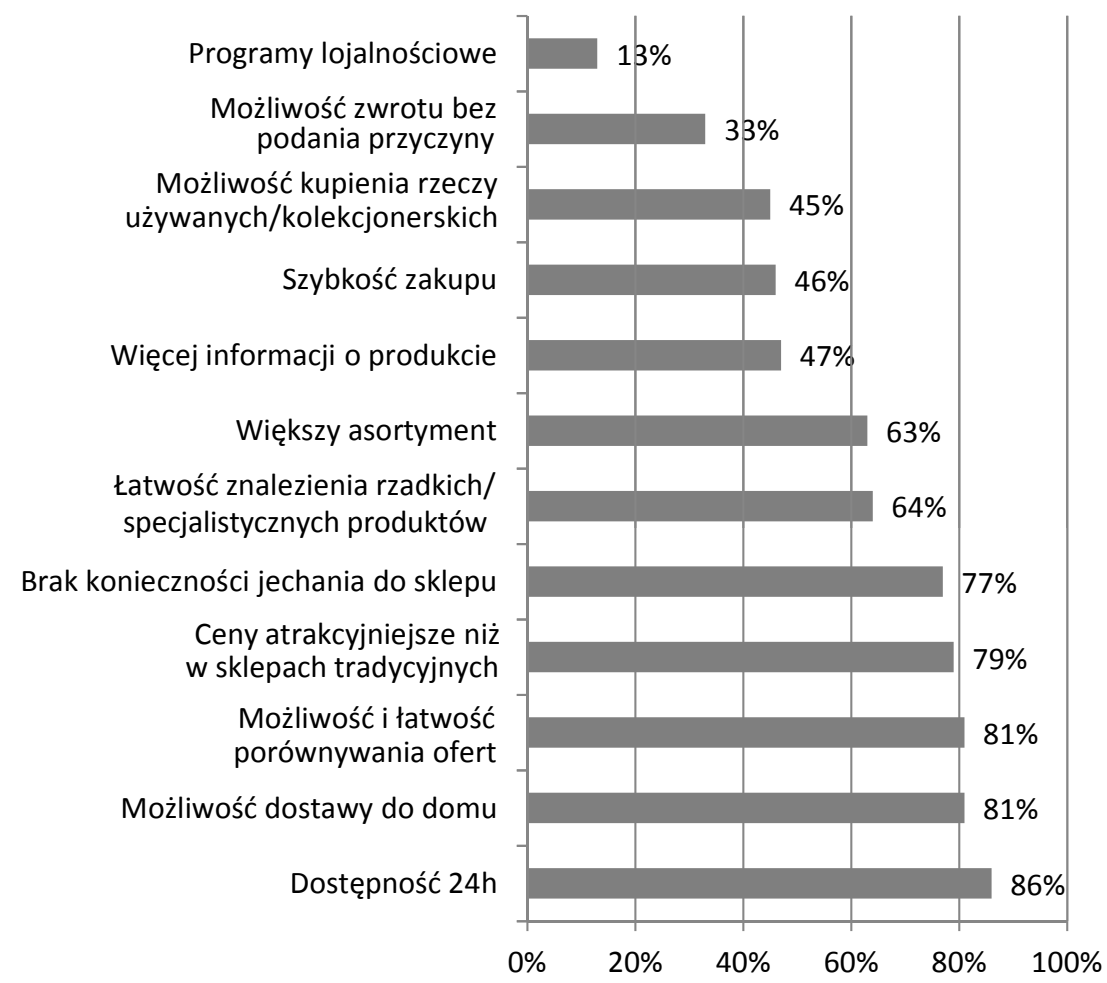

Źródło: E-commerce w Polsce 2014. Gemius dla e-Commerce Polska, www.ecommerce.gemius.pl/ (dostęp 21.03.2015). 
Najczęstszym powodem decyzji o zakupach w Internecie jest możliwość ich dokonania o każdej porze dnia i nocy, następnie dostawa do domu oraz łatwość porównywania ofert. Niższa cena niż w sklepie tradycyjnym znalazła się dopiero na 4. miejscu. Taka forma zakupów jest wygodna i umożliwia szerszy dostęp do produktów, przez co decyzje konsumentów są bardziej świadome i przemyślane. Sprzedawcy natomiast mają dostęp do większych rynków zbytu. Dochodzą do tego jeszcze korzyści związane z mniejszym zużyciem zasobów przy sprzedaży elektronicznej w porównaniu ze sprzedażą tradycyjną.

Kolejnym pozytywnym zjawiskiem wśród polskich konsumentów jest zmiana przyzwyczajeń oraz realizacja tzw. inteligentnej konsumpcji, nawiązującej swymi założeniami do konsumpcji zrównoważonej. Zachowania uznawane przez polskie społeczeństwo za lepszą konsumpcję przedstawiono na rysunku 3.

Rysunek 3. Polskie rozumienie lepszej konsumpcji

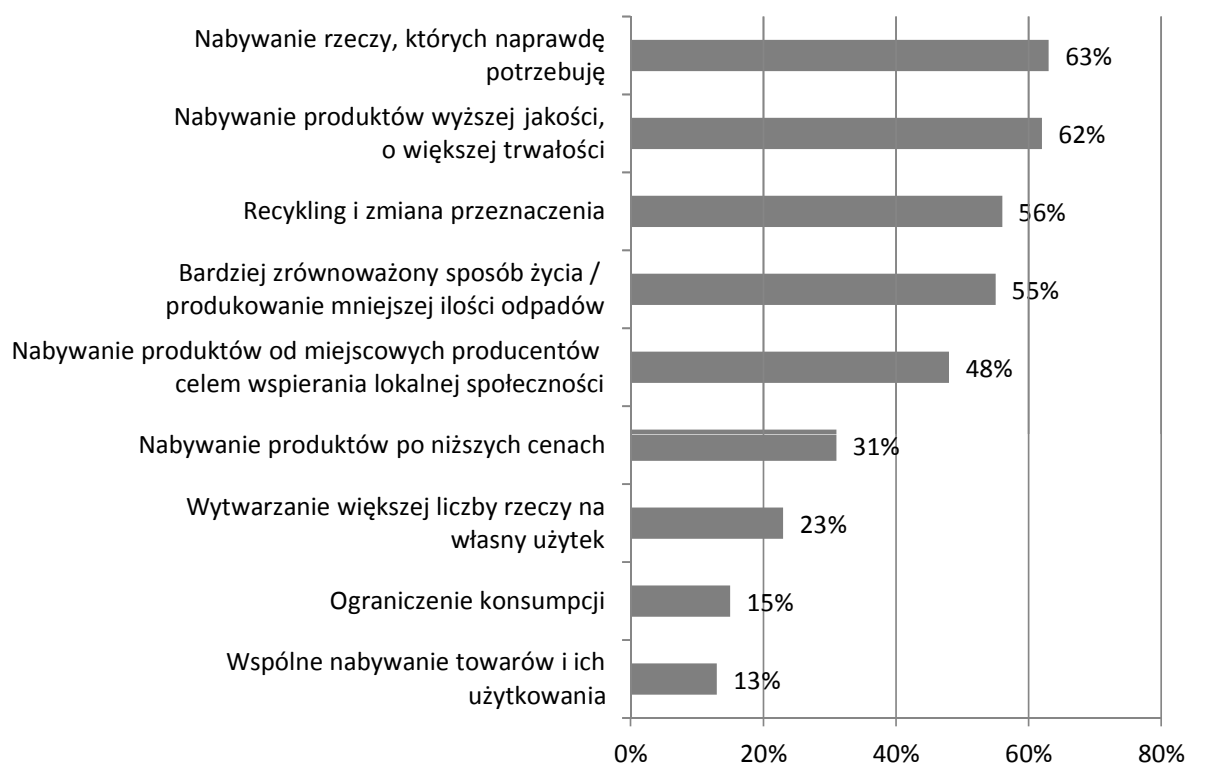

Źródło: Raport Havas Worldwide, Nowy typ konsumentów...

Ponad połowa badanych uważa, że konsumpcja inteligentna realizowana jest wówczas, gdy: nabywa się jedynie rzeczy niezbędne (63\%), o wyższej jakości 
(62\%), konsumowane dobra poddaje się procesom recyklingu czy zmienia się ich przeznaczenie (56\%) lub żyje się w sposób bardziej zrównoważony, utożsamiany z produkcją mniejszej ilości odpadów (55\%). Co ciekawe, w grupie 30- i 40-latków $100 \%$ ankietowanych uznało, że lepsza konsumpcja to kupowanie tylko rzeczy potrzebnych. Wykazywali oni również zdecydowanie większą tendencję do ponownego wykorzystywania rzeczy, a tym samym wydłużenia okresu ich żywotności (63\%). Wśród powodów zakupu rzeczy używanych najczęściej wymieniano: oszczędności, korzystniejszy wpływ na środowisko, pomoc sprzedawcy oraz ciekawa historia przedmiotu $^{15}$.

Nieco mniej niż połowa ogółu badanych w Polsce uważa, że powinno się kupować produkty od miejscowych producentów w celu wspierania lokalnych firm. $\mathrm{Z}$ drugiej strony jest to wiara, że produkty te są zdrowsze i jakościowo lepsze niż dobra z produkcji masowej światowych koncernów. Mniejsze poparcie uzyskała produkcja własna. $23 \%$ uznało wytwarzanie na własny użytek (np. uprawę warzyw w ogródku, wytwarzanie świec) jako sposób na poprawę zachowań konsumpcyjnych. Za nowym zjawiskiem, jakim jest wspólne nabywanie i współużytkowanie produktów, opowiedziało się jedynie 13\%. Największe uznanie tego typu działalność znalazła wśród osób w wieku 16-34 lat (19\%).

Dotychczasowe przeświadczenie, że aby konsumować dobro, trzeba je posiadać, stopniowo wypiera społeczność współpracy. Ogranicza się gromadzenie dóbr i powoli eliminuje ,zbieractwo”. Ponad połowa badanych jest pewna, że w Internecie zawsze znajdzie się ktoś, kto będzie gotów wypożyczyć/wynająć przedmiot, którego akurat potrzebuje. A dzięki dostępności różnorodnych portali aż 59\% odsprzedaje lub oddaje niepotrzebne już rzeczy, które wcześniej były wyrzucane. Ze zdaniem „Wolę współużytkować, niż posiadać rzecz” zgodziło się $63 \%$ polskich ankietowanych, jedynie $14 \%$ miało na ten temat przeciwne zdanie. W ujęciu światowym na tak było $46 \%$, a na nie $-22 \%$ badanych ${ }^{16}$. Powody, dla których jednostki decydują się na współdzielenie, przedstawiono na rysunku 4.

\footnotetext{
${ }^{15}$ Raport Havas Worldwide, Nowy typ konsumentów...

16 Ibidem.
} 
Rysunek 4. Korzyści ze współużytkowania

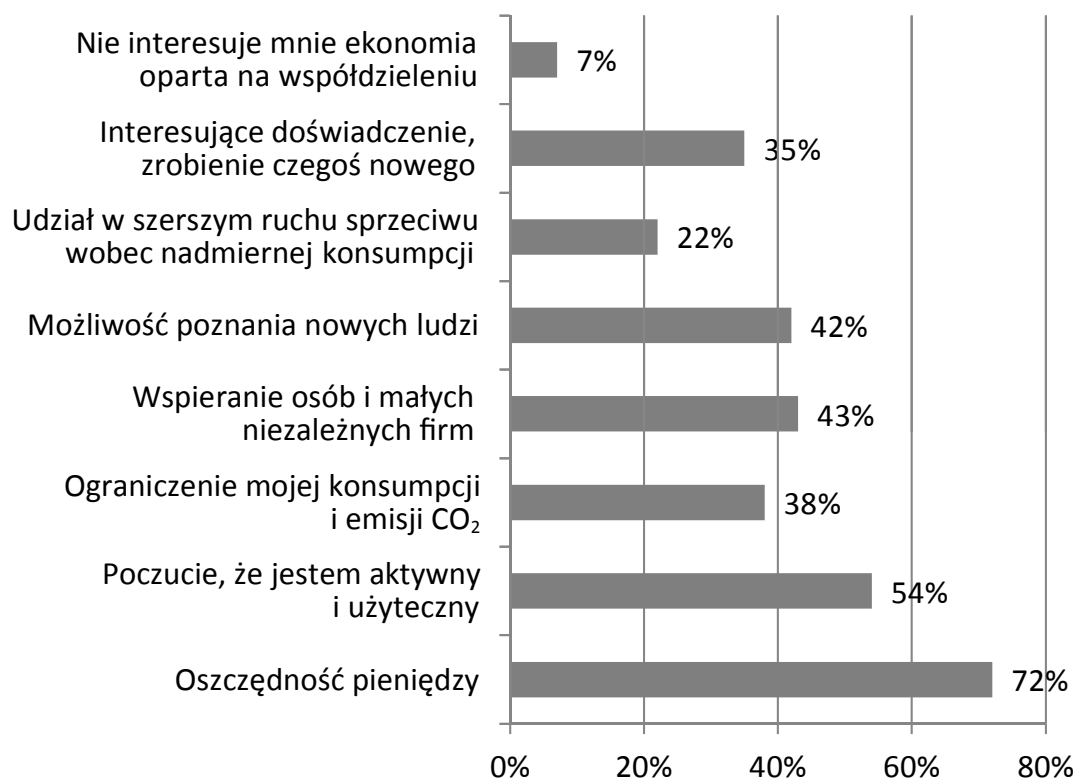

Źródło: jak pod rysunkiem 3.

Pomimo wskazywania aspektów ekologicznych ekonomii współdzielenia, dominującym argumentem jest oszczędność pieniędzy, kolejnym własna aktywizacja oraz poczucie użyteczności społecznej. 7\% badanych w ogóle nie jest zainteresowanych ekonomią współdzielenia. Dobra zadeklarowane jako udostępniane oraz użytkowane najczęściej na zasadzie wymiany ujęto w tabeli 1 .

Tabela 1. Dobra, z jakich skorzystano by lub wypożyczono obcej osobie na zasadzie wymiany

\begin{tabular}{|l|c|c|}
\hline \multicolumn{1}{|c|}{ Przedmiot } & Wypożyczenie (\%) & Wykorzystanie (\%) \\
\hline Urządzenia (np. wiertarka, kosiarka) & 67 & 63 \\
\hline $\begin{array}{l}\text { Multimedia i osobiste urządzenia } \\
\text { elektroniczne }\end{array}$ & 34 & 68 \\
\hline Samochód & 12 & 27 \\
\hline Mieszkanie/dom & 13 & 45 \\
\hline
\end{tabular}

Źródło: jak pod rysunkiem 3. 
Wyraźnie widać, że ludzie chętniej skorzystaliby z możliwości wypożyczenia potrzebnych rzeczy od innych niż sami udostępniliby własne. Największą popularnością współużytkowania cieszą się różnego rodzaju sprzęty, takie jak wiertarka, kosiarka, użytkowane od czasu do czasu, a także multimedia, np. gry komputerowe, wideo, książki, płyty czy DVD. Dodatkowo wśród rzeczy, jakimi dzielą się Polacy poprzez serwisy wymiany, znalazły się sprzęt sportowy oraz ubrania i dodatki. 19\% badanych zadeklarowało, że żadnej rzeczy nie pożyczyłoby obcej osobie.

\section{Zachowania konsumentów a kondycja gospodarki}

Współczesny konsument nie jest już biernym odbiorcą dóbr oferowanych przez firmy, lecz sam stawia im konkretne warunki i wymagania, zmuszając je do określonych działań. Informacji na temat specyfiki i ceny produktu oraz opinii jego użytkowników wyszukuje w Internecie. Następnie dokonuje zakupu albo w sklepie stacjonarnym, albo w zaciszu domowym w sklepie internetowym. Wychodząc naprzeciw oczekiwaniom klientów, wiele firm przeniosło część swojej działalności w świat wirtualny, zwiększając swój zasięg oraz generując dodatkowe zyski, a z drugiej strony - zmniejszając wydatki na funkcjonowanie sklepu tradycyjnego. Również dla małych rodzinnych biznesów Internet stał się wygodnym i tanim kanałem dotarcia do większego grona odbiorców ${ }^{17}$.

Może się wydawać, że zachowania konsumentów polegające na ograniczaniu wydatków przez nabywanie jedynie rzeczy niezbędnych czy używanych oraz dawanie przedmiotom „drugiego życia” może ujemnie wpłynąć na PKB. Podobnie rzecz ma się z wytwarzaniem na własny użytek czy współużytkowaniem. Nic bardziej mylnego, gdyż owe trendy dają tak naprawdę nowe możliwości, innowacyjne, dostosowane do potrzeb człowieka i jego stylu życia, nowe kanały sprzedaży i nowe formy konsumpcji. Tendencje te, realizowane w myśl idei zrównoważonej konsumpcji i zrównoważonego rozwoju, odpowiednio wykorzystane pozwolą nawet na zwiększenie konsumpcji oraz wzrost PKB, przy jednoczesnym ograniczaniu marnotrawstwa oraz mniejszym i lepszym wykorzystaniu zasobów ${ }^{18}$. Ich pozytywnym

${ }^{17}$ S. Behrendt, Ch. Henseling u.a., Vom Consumer zum Prosumer - Potenziale für nachhaltigen Konsum durch den Wandeln der Konsumentenrolle in der Internetökonomie, w: Vom Wissen zum Handeln - Neue Wege zum Nachhaltigen Konsum, Statusheft von BMBF und SÖF 2009, s. 47-48.

${ }^{18}$ K. Brzoska, A. Lewandowska, Wzrost gospodarczy w dobie zrównoważonego rozwoju, w: Problemy Gospodarki Światowej, t. III, red. M. Kuczmarska, I. Pietryka, Wydawnictwo Instytutu Badań Gospodarczych i Polskiego Towarzystwa Ekonomicznego oddział w Toruniu, Toruń 2013, s. 83-97. 
oddźwiękiem będzie także produkcja dóbr o wyższej jakości, co jest równoważne z dłuższym okresem ich funkcjonowania, a tym samym i generowanie mniejszej ilości odpadów. Co ciekawe, przedsiębiorstwa same podejmują liczne inicjatywy, by być bardziej przystępnymi i przyjaznymi dla współczesnych konsumentów, a nierzadko włączają ich do procesu kreacji produktów i usług ${ }^{19}$. Przykładem mogą być akcje wymiany starych produktów na nowe po niższej cenie, podczas gdy te zużyte zostają poddane recyklingowi lub są zagospodarowywane w różnoraki sposób. Dochody firm rosną, podobnie jak dochody portali zajmujących się pośrednictwem w procesie współdzielenia.

Większa świadomość i wyważone decyzje nabywców determinują zmianę oraz nowe zachowania konsumentów, które kolejno skłaniają do zmiany zachowań również przedsiębiorstwa handlowe i produkcyjne. Powiązane ze sobą konsumpcja inteligentna i zrównoważona $\mathrm{w}$ dalszym ciągu mogą napędzać koniunkturę gospodarczą, z tą tylko różnicą, że będzie to zdrowy dobrobyt, korzystny dla gospodarki, środowiska i społeczeństwa.

\section{Podsumowanie}

Decyzje konsumpcyjne, w kontekście złożoności świata i procesów gospodarczych, zostały zdeterminowane wielością czynników i postawami samego człowieka. Analizowane dane wyraźnie wskazują, że rośnie znaczenie Internetu jako podstawowego kanału sprzedaży. Zwiększa się liczba zwolenników i użytkowników narzędzi e-commerce, a dynamiczny wzrost udziałów tego rynku powinien się utrzymać. Odpowiednio zorganizowana sprzedaż online będzie szansą na podniesienie dochodów, a tym samym i przyczyni się do rozwoju społeczno-gospodarczego zmniejszającego degradację środowiska i ograniczającego nadmierne zużywanie zasobów, czyli do rozwoju zrównoważonego i trwałego.

Znaczna część polskich konsumentów wykazuje również zachowania typowe dla tzw. inteligentnej konsumpcji, zmierzając ku konsumpcji zrównoważonej. Bardziej świadome i przemyślane decyzje konsumpcyjne, zakup jedynie rzeczy niezbędnych, ponowne wykorzystywanie dóbr czy rozwój wspólnego nabywania i współużytkowania, stają się coraz bardziej popularne i to właśnie one będą wyznaczały przyszły kierunek postępowania konsumentów.

19 E. Abramek, Prosumpcja..., s. 13-14. 


\section{Literatura}

Abramek E., Prosumpcja w rozwoju systemów informatycznych zarzadzania, w: Innowacje w zarządzaniu i inżynierii produkcji, red. R. Knosala, Oficyna Wydawnicza Polskiego Towarzystwa Zarządzania Produkcją, Opole 2013.

Behrendt S., Henseling Ch. u.a., Vom Consumer zum Prosumer - Potenziale für nachhaltigen Konsum durch den Wandeln der Konsumentenrolle in der Internetökonomie, w: Vom Wissen zum Handeln - Neue Wege zum Nachhaltigen Konsum, Statusheft von BMBF und SÖF 2009.

Brzoska K., Lewandowska A., Wzrost gospodarczy w dobie zrównoważonego rozwoju, w: Problemy Gospodarki Światowej, t. III, red. M. Kuczmarska, I. Pietryka, Wydawnictwo Instytutu Badań Gospodarczych i Polskiego Towarzystwa Ekonomicznego oddział w Toruniu, Toruń 2013.

Buss D.M., Psychologia ewolucyjna, Gdańskie Wydawnictwo Psychologiczne, Gdańsk 2001.

E-commerce w Polsce 2014. Gemius dla e-Commerce Polska, www.ecommerce.gemius.pl/ (dostęp 21.03.2015).

http://informacje.havasworldwide.pl/pr/286856/inteligentna-konsumpcja-i-rola-marekw-obliczu-ekonomii-w-sam-raz?rss=true (dostęp 30.03.2015).

Kryk B., Zrównoważona jakość życia a zrównoważona konsumpcja i zachowania ekologiczne polskich konsumentów, „Handel Wewnętrzny”, listopad-grudzień 2013, t. II.

Privater Konsum und Nachhaltige Entwicklung, red. H. Leitschuh-Fecht, S. Lorek, Positionspapier des Forum Umwelt \& Entwicklung, Positionspapier zur Vorlage bei der CSD 7, Bonn 1999.

Loewenstein G., Prelec D., Anomalies in Intertemporal choice: Evidence and an Interpretation, „Quarterly Journal of Economics”, May 2012.

Maty Rocznik Statystyczny Polski 2014, GUS, Warszawa 2014.

Olejniczuk-Merta A., Zmiany w konsumpcji i zachowaniach konsumentów, w: Społeczno-ekonomiczne determinanty konsumpcji w Polsce, red. U. Łangowska-Szczęśniak, A. Bobrowska, Wydawnictwo Uniwersytetu Opolskiego, Opole 2011.

Raport Izby Gospodarki Elektronicznej, Kupuję w internecie 2014, www.ecommercepolska. pl (dostęp 21.03.2015).

Raport Havas Worldwide, Nowy typ konsumentów i gospodarka oparta na współdzieleniu, http://informacje.havasworldwide.pl/pr/286856/inteligentna-konsumpcja-i-rola-marek-w-obliczu-ekonomii-w-sam-raz?rss=true (dostęp 30.03.2015).

Spangenberg J.H., Lorek S., Lebensqualität, Konsum und Umwelt: intelligente Lösungen statt unnötiger Gegensätze, Gutachten, SERI Sustainable Europe Research Institute, Köln-Wien 2003. 
Zaleśkiewicz T., Psychologia ekonomiczna, Wydawnictwo Naukowe PWN, Warszawa 2013. Zrałek J., Dekonsumpcja jako przejaw konsumpcji zrównoważonej i jej konsekwencje dla marketingu, „Handel Wewnętrzny”, maj-czerwiec 2013, t. I.

\title{
BEHAVIORAL ASPECTS OF CONSUMER DECISION IN POLAND AND THEIR IMPORTANCE FOR THE ECONOMY
}

\begin{abstract}
The article describes behaviors that determine decision-making processes of modern consumers. The main aim of this paper is to identify and evaluate the latest trends in consumption and the development of intelligent consumption. The considerations relate only to Polish consumers. In the context of the objectives of sustainable consumption analyzed the effects and significance of consumer behaviors for the economy.
\end{abstract}

Translated by Aleksandra Milczarek

Keywords: consumption, decision making, sustainable consumption, intelligent consumption

JEL Codes: D1, E03, E21 
